\title{
Evaluate the Shelf Life of Rhizobium Carrier Based Biofertilizer Stored at Different Temperatures at Different Intervals
}

\author{
G. Thirumal*, R. Subhash Reddy, S. Triveni, K. Damodarachari and K. Bhavya \\ Department of Agricultural Microbiology and Bioenergy, College of Agriculture, \\ Professor Jaya Shankar Telangana State Agricultural University, Rajendranagar, \\ Hyderabad - 500 030, Telangana, India \\ *Corresponding author
}

\section{A B S T R A C T}

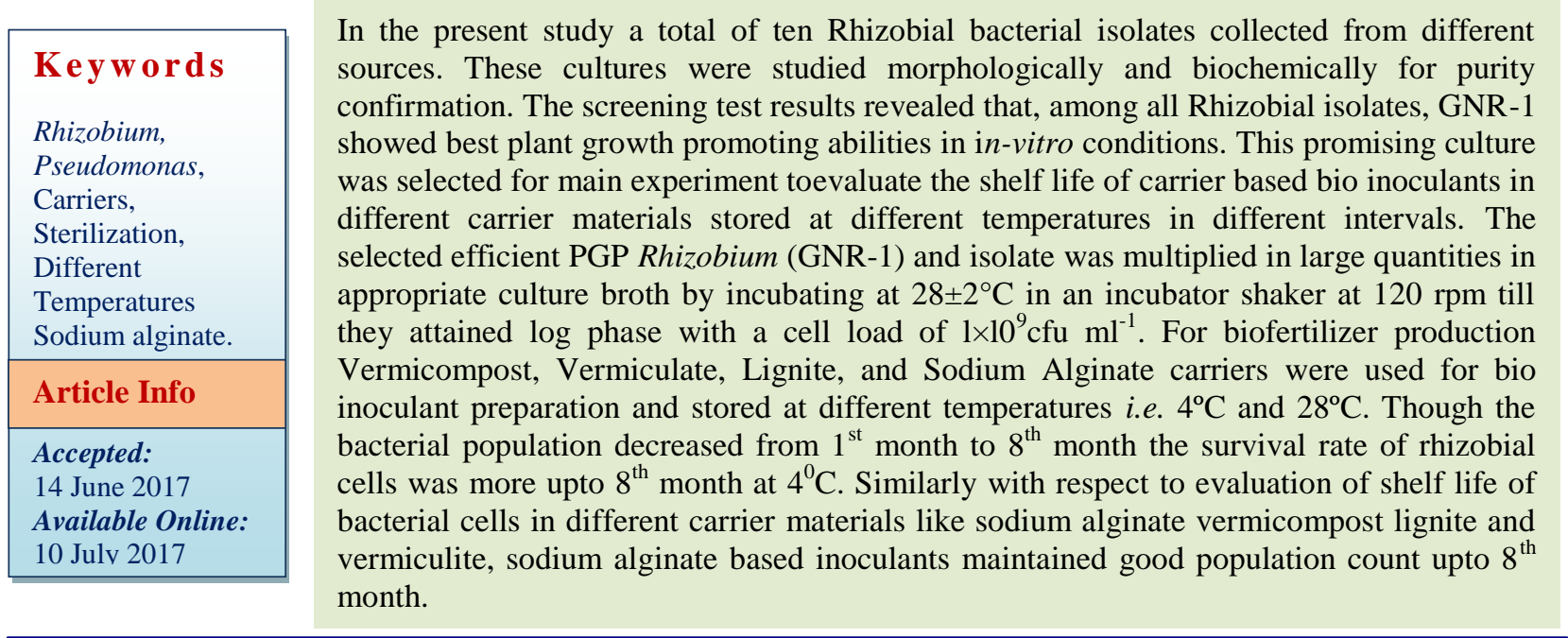

\section{Introduction}

Biofertilizers are identified to have a supplementary role to chemical fertilizers to increase soil fertility and crop production in sustainable farming. Microbial inocula not only increased the assimilation of nutrients by plant (total N, P and K), but also improved soil properties, such as organic matter content and total $\mathrm{N}$ in soil (Wu et al., 2005).

Biofertilizers with solid carrier material can be more advantageously used because they can increase the supply of phosphorus to plant, resistance to soil borne plant pathogens and biological degradation of organic pollutants (Warren et al., 2009). Several alternative carrier material, such as, soil, perlite, polyacrylamide gel, ground rock phosphate, alginate, coal, decomposed saw dust, compost, farmyard manure and volcanic pumice have been evaluated as inoculant carrier (Stephens and Rask, 2000).

No one can deny the importance of chemical fertilizers but high inputs of chemical fertilizers have not only caused environmental problems but also generated human health 
damages. Major portion of applied fertilizers is not available to the plants because it becomes fixed onto the soil particles while remaining part enters into fresh water bodies and cause eutrophication which ultimately deteriorates the water quality (Barlog and Grzebisz, 2004).

Conventional agriculture plays a significant role in meeting the food demands of growing human population, which has also led to an increasing dependence on chemical fertilizers and pesticides (Santoso et al., 2007). About $50 \%$ of applied nitrogen fertilizers enters into the environment from the agricultural lands in the form of nitrates, $\mathrm{N}_{2}$ and $\mathrm{NH}_{3}$ (Tilman, 1998) whereas $90 \%$ of phosphatic fertilizer gets precipitated and causes pollution. Furthermore, excessive use of chemical fertilizers has enhanced emission of greenhouse gases into the environment which damages ozone layer (Ma et al., 2007) and causes global warming (Frink et al., 1999).

John et al., (2006) reported that the increased pathogen attack in aquatic ecosystem might be due to high accumulation of phosphorus and nitrogen from the agricultural lands. Several efforts have been made globally to overcome this major problem. Use of biofertilizer along with the complementary measures is the ultimate strategy for maintaining soil fertility and agricultural sustainability (Graham and Vance, 2000).

\section{Materials and Methods}

The present study was carried out at the Department of Agricultural Microbiology \& Bioenergy, College of Agriculture, Rajendranagar, PJTSAU, and Hyderabad. Pure cultures of Plant Growth Promoting Rhizobium isolates collected from different laboratories. Attempts were made to assess the screening and characterization of isolates with multiple beneficial properties then the efficient PGPR isolate were selected for preparation of carrier based biofertilizers.

\section{Collection of rhizobial isolates from different sources}

Promising bacterial isolates are collected from different laboratories and these isolates were tested for their purity and preservation in Dept. of Agricultural Microbiology \& Bioenergy, College of Agriculture, PJTSAU Rajendranagar, Hyderabad.

\section{Identification of bacterial isolates purity checking}

\section{Morphological and biochemical characterization}

The isolated bacteria were studied for their morphological like gram reaction, pigmentation, cultural characteristics and biochemical characteristics like In dole production, methyl red, Voges-Praskaure's test, citrate utilization test, oxidase, catalase and sugar fermentation tests.

\section{Screening for plant growth promoting properties}

Screening will be carried out for different plant growth promoting properties such as mineral solublization like Phosphorus Solubilisation (Pikovskaya, 1948), Zinc Solubilization (Saravanan et al., 2003), Potassium releasing (Prajapati and Modi, 2012), Plant growth promoting substances such as IAA production (Gorden and Weber, 1951), biocontrol activity such as $\mathrm{HCN}$ production (Castric and Castric, 1983) and Siderophore production (Schwyn and Neilands, 1987) and antifungal activity with soil born plant pathogens all ten isolates were checked for their purity and then studied for the colony morphology and pigmentation. The cell shape and gram reaction were also 
recorded as per the standard procedures given by Barthalomew and Mittewar (1950).

\section{Gram's staining}

A drop of sterile distilled water was placed in the center of glass slide. A loopful of inoculum from young culture was taken, mixed with water, and placed in the center of the slide. The suspension was spread out on slide using the tip of inoculation needle to make a thin suspension.

The smear was dried in air and fixed through mild heating by passing the slide 3 to 4 times over the flame. The smear was then flooded with Crystal violet solution for $1 \mathrm{~min}$ and washed gently with flow of tap water.

Then the slide was flooded with Iodine solution. After incubation at room temperature for $1 \mathrm{~min}$, Iodine solution was drained out followed by washing with $95 \%$ decolorizer. After that, it was washed with water within 15 to $30 \mathrm{sec}$ and blot carefully. The smear was incubated with Saffranin solution for $1 \mathrm{~min}$. The slide was washed gently in flow of tap water and dried in air. The slide was examined under microscope at 100X power with oil immersion and data was recorded.

\section{Cultural characterization}

Morphological characteristics of the colony of each isolate were examined on specialized medium. Cultural characterization of isolates observed by different characteristics of colonies such as shape, size, elevation, surface, margin, colour, odour, pigmentation etc were recorded.

\section{Yeast Extract Mannitol Agar with Congo red test (YEMAC)}

The isolates were streaked on YEMAC media plates and incubated at $28 \pm 20^{\circ} \mathrm{C}$ for $48-72 \mathrm{~h}$.
Rhizobial colonies do not absorb colour and remain white in colour.

\section{Collection of carrier materials}

Sodium alginate collected from Department of Agricultural Microbiology and Bioenergy College of Agriculture Rajendranagar, Hyderabad. Vermiculate collected from Navaratna Crop Science Pvt Ltd, Cherlapally, Hyderabad. Lignite collected from RKVY project in the Department of Agricultural Microbiology and Bioenergy College of Agriculture Rajendranagar, Hyderabad. Vermicompost collected from NIRD Rajendranagar, Hyderabad.

\section{Physico-chemical properties of carriers}

For the preparation of bioformulation, the collected different carriers such as lignite, vermicompost, sodium alginate and vermiculite were tested for their moisture content (Aeron et al., (2011) and pH at initial and end of the experiment.

\section{Autoclave sterilization}

Lignite, Vermicompost, Vermiculate, and Sodium Alginate were sterilized in Tyndalization process in an Autoclave at 15lb psi $\left(121^{\circ} \mathrm{C}\right)$ for $20 \mathrm{~min}$ three times on succeeding days.

\section{Preparation of biofertilizers}

Preparation of carrier based bioformulations

The selected isolate was multiplied in large quantities in appropriate culture broth by incubating at $28 \pm 2^{\circ} \mathrm{C}$ in an incubator shaker till they attained $\log$ phase with a cell load of $1 \times 10^{9} \mathrm{cfu} \mathrm{ml} l^{-1}$ and were used for inoculant preparation. The individual carrier materials were powdered and the $\mathrm{pH}$ was brought to neutral by adding $\mathrm{CaCO}_{3}$ after sterilized at 15 
psi $121^{\circ} \mathrm{c}$ for 1 hour in three successive days after and then mixed with the log phase culture $\left(1 \times 10^{9} \mathrm{cfu} \mathrm{ml} \mathrm{m}^{-1}\right)$ of the selected plant growth promoting bacterial isolate viz., Rhizobium (GNR1) in separate quantities of sterile carrier in shallow trays. The optimum moisture content was adjusted to (30-40\%) prior to preparation, followed by curing in shallow trays for 24 hours in aseptic rooms and then packed in high density opaque polythene bag $(12 \mathrm{~g})$ at the rate of $100 \mathrm{~g} \mathrm{bag}^{-1}$ and sealed. Individual inoculant was prepared by mixing with lignite $(1: 3 \mathrm{v} / \mathrm{w})$, vermicompost $(1: 2 \mathrm{v} / \mathrm{w})$, vermiculite $(1: 2 \mathrm{v} / \mathrm{w})$ volumes of each culture broth with sterile carrier materials. The populations of individual Plant Growth Promoting Rhizobacteria in the inoculant carriers were assessed at monthly intervals upto 8 months.

\section{Preparation of alginate based inoculant}

Rhizobium spp was grown in respective medium to get a population of $1 \times 10^{9} \mathrm{cfu} \mathrm{ml}^{-1}$ Sodium alginate beaded inoculant was prepared as per the methods described by Hegde and Brahmaprakash (1992). Two gram of sodium alginate was added to $100 \mathrm{ml}$ of culture broth of PGPR and mixed for 30 minutes in a magnetic stirrer.

The mixture was added drop wise through a $10 \mathrm{ml}$ syringe into $100 \mathrm{ml}$ sterile $0.1 \mathrm{~N} \mathrm{CaCl}_{2}$ to obtain uniform Alginate beads. One gram of material contained 16 to 17 beads, each bead approximately weighing $60 \mathrm{mg}$. The beads were washed twice in sterile distilled water and incubated for seven days in a psychrotherm (model environ shaker) incubator at $28 \pm 2^{\circ} \mathrm{C}$ to allow PGPR to multiply inside the beads. The beads were again washed in sterile distilled water and air dried in Laminar air flow chamber under aseptic condition. The Alginate beads were then stored in polythene bags at room temperature $\left(28 \pm 2^{\circ} \mathrm{C}\right)$ and refrigerator $\left(4^{\circ} \mathrm{C}\right)$ up to 8 months.
Treatments,

T 1: $\mathrm{S}_{1} \mathrm{C}_{1} \mathrm{O}_{1}$ (Autoclaved Vermicompost with Rhizobium spp)

$\mathrm{T}$ 2: $\mathrm{S}_{1} \mathrm{C}_{2} \mathrm{O}_{1}$ (Autoclaved Sodium alginate with Rhizobium spp)

T3: $\mathrm{S}_{1} \mathrm{C}_{3} \mathrm{O}_{1} \quad$ (Autoclaved Lignite with Rhizobium spp).

T4: $\mathrm{S}_{1} \mathrm{C}_{4} \mathrm{O}_{1}$ (Autoclaved Vermiculite with Rhizobium spp),

Determination of viable bacterial population in the carrier based inoculants by serial dilution and plating technique. Influence of storage temperature on the survival of the inoculants as consortium in different carrier materials. The carrier based microbial inoculants prepared with different carrier material was kept in different temperature levels viz., Room temperature $\left(28 \pm 2^{\circ} \mathrm{C}\right)$ and Refrigerator $\left(4^{\circ}\right)$. The surviving populations of PGPB at different temperatures were determined and population was enumerated by dilution plate technique at different intervals i.e., monthly upto 8 months.

\section{Results and Discussion}

At $4^{\circ} \mathrm{C}$ storage temperature, autoclave sterilized vermicompost, sodium alginate, lignite, vermiculite based rhizobial inoculants, rhizobial bacterial population decreased from $1^{\text {st }}$ month to $8^{\text {th }}$ month table 1 .

At $28 \pm 2^{\circ} \mathrm{C}$ storage temperature also autoclave sterilized all carrier based rhizobial inoculants, rhizobial bacterial population decreased from $1^{\text {st }}$ month to $8^{\text {th }}$ month table 2 . But survival rate of rhizobial cells was more upto $8^{\text {th }}$ month at $4^{\circ} \mathrm{C}$ compared to $28 \pm 2^{\circ} \mathrm{C}$. This results revealed that $4^{\circ} \mathrm{C}$ storage temperature is best suitable for storage of carrier based inoculants because of low level of moisture content in the carrier inoculants stored at $28 \pm 2^{\circ} \mathrm{C}$ temperature. 
Table.1 Rhizobium population in different carrier based bio inoculants at $4^{\circ} \mathrm{C}$ up to 8 months

\begin{tabular}{|c|c|c|c|c|}
\hline \multirow{2}{*}{ Month } & Vermicompost & \multirow{2}{*}{$\begin{array}{c}\text { Sodium } \\
4^{\circ} \mathrm{C}\end{array}$} & Lignite & Vermculite \\
\cline { 4 - 5 } & 9.58 & 9.64 & $4{ }^{\circ} \mathrm{C}$ & $4^{\circ} \mathrm{C}$ \\
\hline 1 & 9.56 & 9.62 & 9.6 & 9.61 \\
\hline 2 & 9.48 & 9.58 & 9.44 & 9.56 \\
\hline 3 & 9.26 & 9.52 & 9.2 & 9.5 \\
\hline 4 & 8.96 & 9.4 & 8.85 & 9.4 \\
\hline 5 & 8.73 & 9.3 & 8.55 & 8.26 \\
\hline 6 & 8.4 & 9.1 & 8.18 & 8.89 \\
\hline 7 & 7.42 & 8.8 & 7 & 7.73 \\
\hline 8 & & \multicolumn{3}{|c}{} \\
\hline
\end{tabular}

Table. 2 Rhizobium population in different carrier based bio inoculants at $28 \pm 2^{\circ} \mathrm{C}$ up to 8 months

\begin{tabular}{|c|c|c|c|c|}
\hline \multirow{3}{*}{ Month } & Vermicompost & $\begin{array}{l}\text { Sodium } \\
\text { alginate }\end{array}$ & Lignite & Vermculite \\
\cline { 2 - 5 } & $28^{\circ} \mathrm{C}$ & $28^{\circ} \mathrm{C}$ & $28^{\circ} \mathrm{C}$ & $28^{\circ} \mathrm{C}$ \\
\hline 1 & 9.85 & 9.92 & 9.8 & 9.9 \\
\hline 2 & 9.77 & 9.84 & 9.74 & 9.8 \\
\hline 3 & 9.66 & 9.75 & 9.63 & 9.69 \\
\hline 4 & 9.34 & 9.54 & 9.27 & 9.33 \\
\hline 5 & 8.6 & 9.18 & 8.45 & 8.78 \\
\hline 6 & 8.2 & 8.7 & 7.8 & 8.42 \\
\hline 7 & 7.6 & 8.16 & 7.4 & 8 \\
\hline 8 & 6.8 & 7.35 & 6.5 & 7 \\
\hline
\end{tabular}

Fig.1

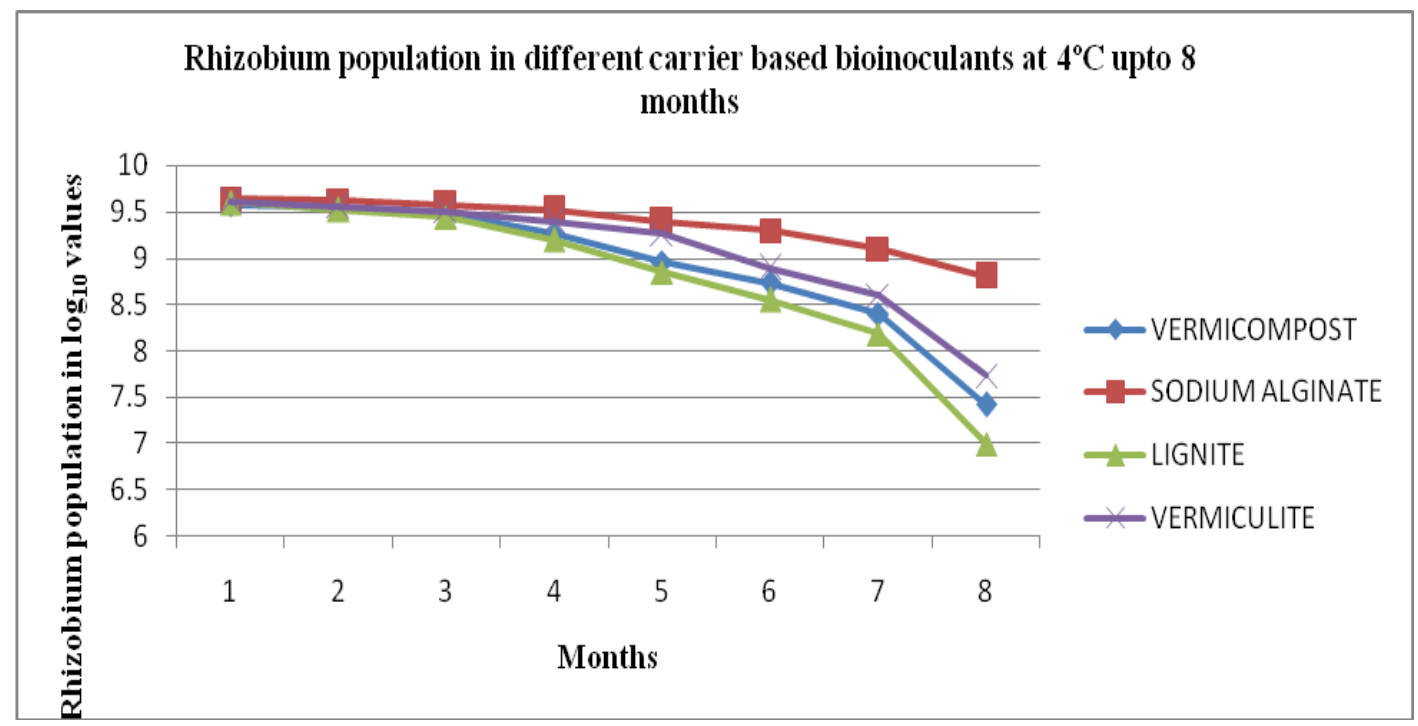


Fig.2

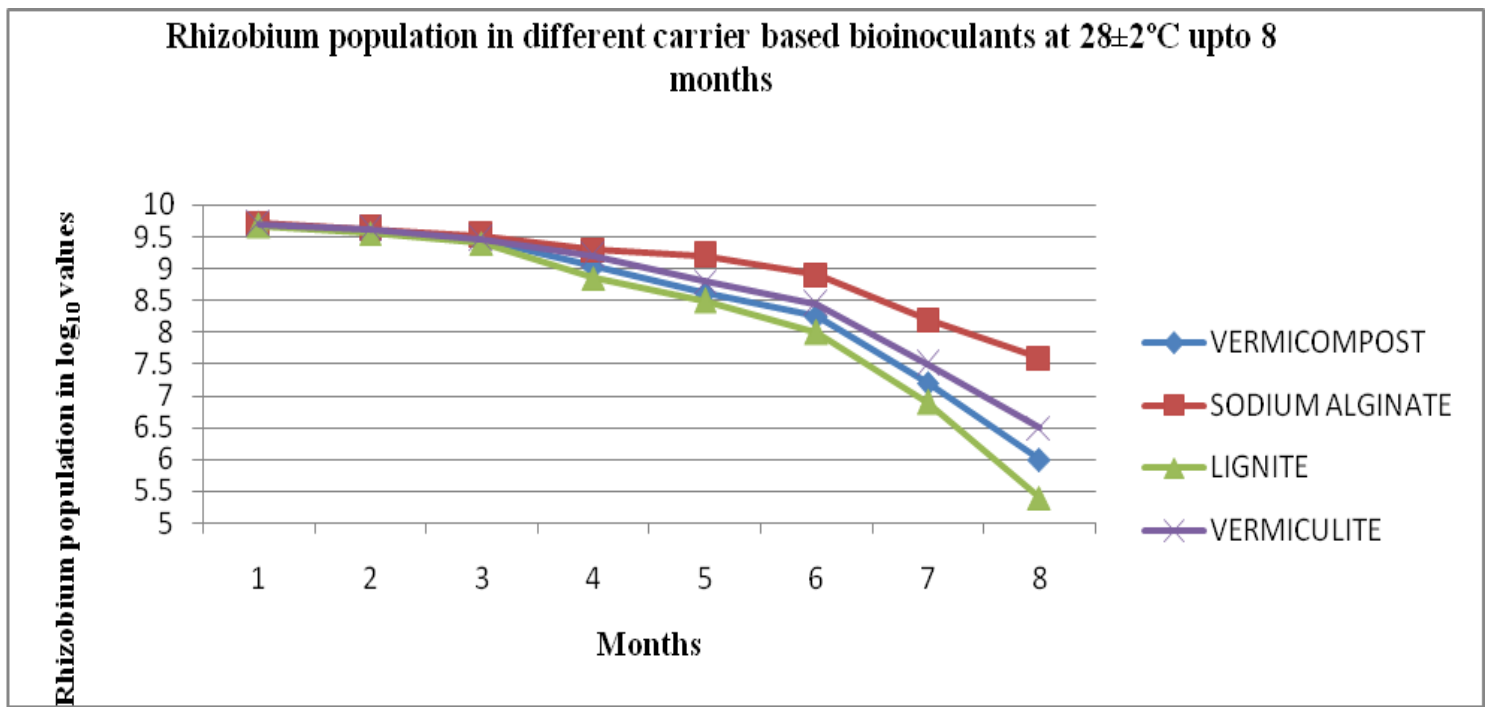

As per specification of biofertilizers, carrier should be minimum $5 \times 10^{7} \mathrm{cfu} \mathrm{g}^{-1}\left(7.6 \log _{10}\right)$ viable count of powdered form of carrier based biofertilizer. So that the above results revealed that at $4^{\circ} \mathrm{C}$, autoclave sterilized vermicompost and lignite carrier based rhizobial bio inoculants supported and maintained optimum viable count $\left(5 \times 10^{7} \mathrm{cfu}\right.$ $\mathrm{g}^{-1}$ ) upto $7^{\text {th }}$ month only, whereas sodium alginate and vermiculite based carrier bio inoculants supported and maintained optimum viable count $\left(5 \times 10^{7} \mathrm{cfu}^{-1}\right)$ upto $8^{\text {th }}$ month figure 1. At $28^{\circ} \mathrm{C}$, autoclave sterilized vermicompost and lignite carrier based rhizobial inoculants supported and maintained optimum viable count $\left(5 \times 10^{7} \mathrm{cfu} \mathrm{g}^{-1}\right)$ upto $6^{\text {th }}$ month only, but sodium alginate and vermiculite based carrier bio inoculants supported and maintained optimum viable count $\left(5 \times 10^{7} \mathrm{cfu} \mathrm{g}^{-1}\right)$ upto $7^{\text {th }}$ month figure 2 .

In conclusion, the production rhizobium carrier based biofertilizer sodium alginate is best in the view of shelf life of bio inoculants, for the longer storage purpose have to keeping in $4^{\circ} \mathrm{C}$ or refrigerated to maintain viability.

\section{References}

Aeron, A., Dubey, R.C., Maheshwari, D.K., Pandey, P., Bajpai, V.K., Kang, S.C. 2011.Multifarious activity of bioformulated Pseudomonas fluorescens PS1 and biocontrol of Sclerotinia sclerotiorum in Indian rapeseed (Brassica campestris L.). European Journals of Plant Pathology. 131: 8193.

Barlog, P and Grzebisz, W. 2004. Effect of timing and nitrogen fertilizer application on winter oilseed rape (Brassica napus L.). II. Nitrogen uptake dynamics and fertilizer efficiency. Jounal of Agronomy Crop Sciences. 190: 314-323.

Barthalomew, J.W and Mittewer, T. 1950. A simplified bacterial strain. Stain Technology. 25: 153.

Castric, K.F and Castric, P.A. 1983. Method for rapid detection of cyanogenic bacteria. Applied and Environmental Microbiology. 45: 700-702.

Frink, C.R., Waggoner, P.E., Ausubel, J.H. 1999. Nitrogen fertilizer: retrospect and prospect. Proc National Academy Sciences. 96: 1175-1180.

Gorden, A.S and Weber, R.P. 1951. Colorimetric estimation of Indole 
Acetic Acid. Plant Physiology. 26: 192195.

Graham, P.H and Vance, C.P. 2000. Nitrogen fixation in perspective, an overview of research and extension needs. Field Crops Research. 65: 93106.

Hegde S, V., Brahmaprakash G. P. 1992. A dry granular inoculant of Rhizobium for soil application. Plant and Soil.144, (2): 309-311

John, P.S., George, $\mathrm{M}$ and Jacob, D. 2006.Sulphur fertilization in rice based cropping system in laterite soils of Kerala. In, TSI-FAI-IFA Symposiumcum-workshop on sulphur in balanced fertilization. 4 (5): 163-184.

Ma, J., Li, XL.,Xu, H., Han, Y., Cai, Z.C and Yagi, K. 2007. Effects of nitrogen fertilizer and wheat straw application on $\mathrm{CH}_{4}$ and $\mathrm{N}_{2} \mathrm{O}$ emissions from a paddy rice field. Australian Journal of Soil Research. 45: 359-367.

Pikovskaya, R.I. 1948. Mobilization of phosphorus in soil connection with the vital activity of some microbial species.Microbiologiya.17: 362-370.

Prajapati, K.B and Modi, H.A. 2012.isolation and characterization of potassium solubilizing bacteria from ceramic industry soil. CIB. Tech Journal of Microbiology.1 (2-3).

Santoso, S.E., Soesanto, L and Haryanto, T.A.D. 2007. Biological suppression of Fusariumwilt on shallot by Trichoderma harzianum, Trichoderma koningii and Pseudomonas fluorescensP60. Journal Hama danPenyakitTumbuhanTropika. 7 (1): 53-61.

Saravanan, V.S., Subramoniam, S.R and Raj, S.A. 2003. Assessing in Vitro solubilization potential of different zinc solubilizing bacterial ( $\mathrm{ZnSB})$ isolates. Brazilian Journal of Microbiology.34: 121-125.

Schwyn, B. and Neilands, J.B. 1987. Universal chemical assay for the detection and determination of siderophores. Analytical Biochemistry. 160: 47-56. Solubilizing bacteria from ceramic industry soil. CIBTech Journal of Microbiology.

Stephens, J.H.G and Rask, H. 2000. Inoculant production and formulation. Field Crops Research. (65): 294-258.

Tilman, D. 1998. The greening of the green revolution. Nature. 396: 211-212.

Vol. 1 (2-3).

Warren, G.P., Robinson, J.S and Someus, E. 2009. Dissolution of phosphorus from animal bone char in12 soils. Nutrient Cycling in Agroecosystems. (84): 167168.

Wu, S.C., Cao, Z.H., Lib, Z.G., Cheung, K.C and Wong, M.H. 2005. Effects of biofertilizer containing $\mathrm{N}$-fixer, $\mathrm{P}$ and $\mathrm{K}$ solubilizers and AM fungi on maize growth a greenhouse trial. Science Direct. 125: 155-166.

\section{How to cite this article:}

Thirumal, G., R. Subhash Reddy, S. Triveni, K. Damodarachari and Bhavya, K. 2017. Evaluate the Shelf Life of Rhizobium Carrier Based Biofertilizer Stored at Different Temperatures at Different Intervals. Int.J.Curr.Microbiol.App.Sci. 6(7): 753-759.

doi: https://doi.org/10.20546/ijcmas.2017.607.094 